Fisheries Research

April 2015, Volume 164 Pages 238-248

http://dx.doi.org/10.1016/j.fishres.2014.11.019

http://archimer.ifremer.fr/doc/00248/35882/

(c) 2014 Elsevier B.V. All rights reserved.

\title{
Characterizing catches taken by different gears as a step towards evaluating fishing pressure on fish communities
}

\author{
Fauconnet Laurence ${ }^{1, *}$, Trenkel Verena ${ }^{1}$, Morandeau Gilles ${ }^{2}$, Caill-Milly Nathalie ${ }^{2}$, \\ Rochet Marie-Joelle ${ }^{1}$
}

${ }^{1}$ IFREMER, Département Écologie et Modéles pour l'Halieutique, B.P. 21105, 44311 Nantes Cedex 03, France

2 IFREMER, Laboratoire Ressources Halieutiques Aquitaine, UFR Côte Basque, 1 allée du Parc Montaury, 64600 Anglet, France

*Corresponding author : Laurence Fauconnet, email address : laurence.fauconnet@ifremer.fr

\begin{abstract}
:
To implement an ecosystem approach to fisheries management, there is a need to characterize the total pressure exerted by fisheries at the community level. French onboard observer data were used to derive catch metrics and compare fishing distribution across community components between two sites in the Southern Bay of Biscay. Sample-based rarefaction curves were used to standardize metrics across different active and passive gears, and correct for sample size differences. Six metrics for species, length and functional catch composition were tested. Length and functional metrics were found the most relevant metrics to highlight differences in catches between gears, sites, and gear-site interactions. Significant differences were found between gears, mainly in mean length and proportion of piscivores. None of the gears had the most diverse catch across all metrics. Small differences were found between sites, mainly in length range and species richness.
\end{abstract}

Keywords : Catch diversity, Gear comparison, Multivariate analyses, Southern Bay of Biscay 


\section{Introduction}

The ecosystem approach to fisheries (EAF) aims at maintaining ecosystem productivity for present and future generations by balancing multiple societal objectives (Garcia et al., 2003). One goal of fisheries management under an EAF

5 is to keep fishing impacts on the ecosystem within acceptable limits, where the ecosytem structure and functioning is not threatened. The causal relationships formalized under the Driver - Pressure - State - Impact - Response (DPSIR) framework can help management. In particular, pressure can be ajusted by managers to keep the state of marine communities within, or move it towards, acceptable limits (Piet et al., 2006).

While methods exist and are commonly used to characterize fishing pressure on target populations, the limited knowledge on the biology and ecology and lack of fisheries data for most species imply that fishing pressures can not be characterized by fishing mortality or harvest rate at the community level (Piet et al., 2006). It has been hypothesized that both the total amount of fishing, and the way fishing pressure is distributed among ecosystem components determine fishing impacts on the community level (Garcia et al., 2012). Therefore, to develop an EAF, there is a need to characterize fishing pressure at the community level, i.e. the mortality caused by all fishing gears deployed in a given fishing ground on commercial and non-commercial species. Indicators are necessary tools to support this task as they provide information on the range and intensity of effort and mortality (Jennings, 2005; Piet et al., 2006). Two aspects of fishing pressure can be considered at the community level : fishing intensity and distribution across community components. In this study, we focus on how pressure is distributed across community components.

Pressures exerted on marine communities have long been considered only through the landings as declared by fishers and recorded on markets. However, landings represent only part of what is caught by fishers. Discards can make up a significant part of the catch, depending on the gear, area, season and species (Cornou et al., 2013; Hall et al., 2000), including for passive 
gears (Morandeau et al., 2014). Most individuals when discarded are dead, and even if few studies have been undertaken on the survival of species that are released alive, a high level of mortality is assumed (Hall et al., 2000; Revill, 2012). Onboard observer programmes were developped to address the need to identify and quantify the whole catch, distinguished between landings and discards (Alfaro-Shigueto et al., 2010; Attwood et al., 2011). By providing information on the amount, diversity and body size of the catch, onboard observer data are a valuable source to describe fisheries catches at the community level in its multiple dimensions such as species, length, and functional composition.

Onboard observer programmes further provide data on the characteristics and conditions of the fishing operations and on the main fishing metiers. Fishing mortality is likely to differ between gears (Piet et al., 2006). Therefore fishing pressure should be characterized by gear. Given the large diversity of gear characteristics, a gear can be defined at different levels of precision. The fishing method or gear group as defined by the European Union (EU) Data Collection Framework (DCF; European Union, 2008), e.g. bottom trawls or mid-water trawls, subsequently called 'gear' was chosen in this study.

The catch composition reflects both the selective properties of the gear and how it is operated, and the available fish community. In order to study the effect of the gear on the catch composition, we selected two sites in the Southern Bay of Biscay that are structurally and ecologically broadly similar, but differ in their exploitation though they are partly exploited by similar gears (see Section 2.1). Demersal and pelagic fisheries operate in both sites. In the most Southern site, the coastal area in ICES rectangle $16 \mathrm{E} 8$, the area located within 3 miles from the coast and part of the 3-6 miles band, is prohibited to bottom and pelagic trawlers (figure 1 ; Sanchez et al., 2013). This site is consequently mostly harvested by passive fishing gears (figure 1). In the second site located further North, the coastal area in ICES rectangle 19E8, trawling is allowed due to exemptions limiting the application of the trawling ban inside the 3 miles limit 60 (Le Tixerant, 2006). This site is mostly exploited by active gears (figure 1). These study sites are well suited to test the relevance of metrics and highlight 
differences between gears and sites.

Data from the French onboard observer programme were used to compare the catch for all species between gears and sites. However, the onboard observer sampling plan was not established for this purpose, but for estimating discarded amounts per fishing métier. Therefore, the sample size was heterogeneous between gears and sites. Sample size is known to affect catch composition, especially its diversity (Magurran \& McGill, 2011). Besides, different gears use different capture processes, mainly based on fish behaviour (Huse et al., 1999).

70 A fishing operation from a given gear is not directly comparable with a fishing operation from another gear, especially when comparing passive and active gears. Therefore, metrics needed to be standardized before they could be compared.

The objectives of this study were : i) to propose a method to standardize 75 and compare the distribution of catches across community components between passive and active fishing gears based on different sample size, and ii) to propose relevant metrics to characterize the catches that can highlight differences between gears.

\section{Materials and methods}

so 2.1. Study sites

The structure and sediments of the continental shelf in the Southern Bay of Biscay are homogeneous all along the coast of Aquitaine (Le Suavé et al., 2000). Sediments are mostly sandy, except in the deep environment of the Capbreton canyon, which is composed by a mix of rocks, coarse sediments and mudflats. This geological formation favours the presence of species and life stages which live in deeper areas, such as mature hake (Merluccius merluccius ; Sanchez \& Gil, 2000). The Southern Bay of Biscay is important for migratory species like meagre (Argyrosomus regius) in particular for feeding (Sourget \& Biais, 2009). The Southern Bay of Biscay is also the geographic

90 Northern limit of some species belonging to the Sparidae family (Quéro \& Vayne, 


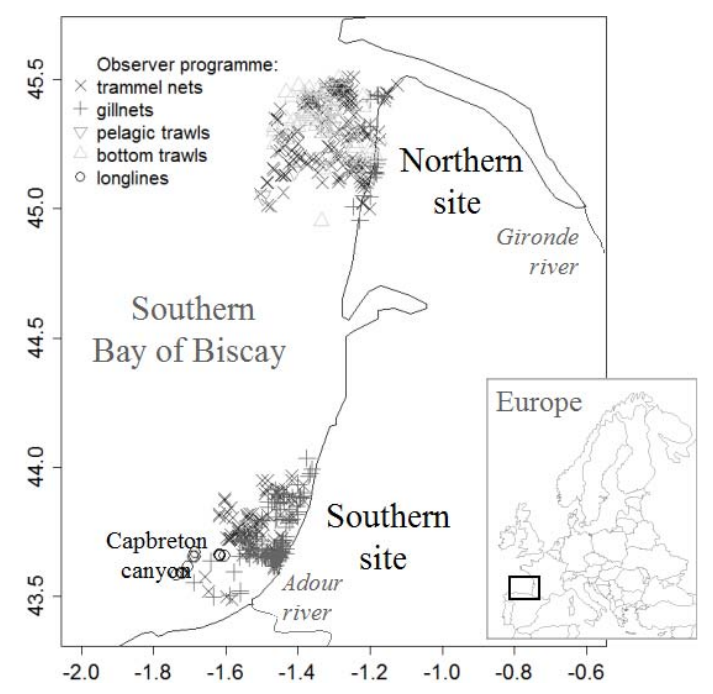

Figure 1: Map of sampled fishing operations observed by gear onboard fishing vessels (20032012) in the Southern site and in the Northern site in the Southern Bay of Biscay (inset).

2005). Habitats and associated communities of the two sites are influenced by the plume of major rivers: Adour River for the Southern site, Gironde for the Northern site (figure 1). River plumes provide habitat for spawning and feeding for many species such as hake, monkfish (Lophius piscatorius and L. budegassa), sea bass (Dicentrarchus labrax), common sole (Solea solea ; Le Pape et al., 2003), turbot (Scophthalmus maximus), mackerels (Scomber scombrus and S. colias ; Borja et al., 2002), anchovy (Engraulis encrasicolus ; Borja et al., 1998). For those reasons, the two sites, situated $100 \mathrm{~km}$ apart, are considered ecologically broadly similar.

A major difference between the sites lies in the fact that, because of differences in access conditions for trawlers, they are harvested by different combinations of fishing gears. The Southern site is exploited by pelagic (purse seiners, baitboaters and pelagic trawlers) and demersal (gillnetters, longliners and pots) fisheries, most of which use passive gears. Pelagic species constitute the most abundant fish in the catch with mackerels, pilchard (Sardina pilchardus), horse mackerel (Trachurus trachurus), anchovy and tunas (Thunnus alalunga and T. 
thynnus). Pelagic species are caught by a few boats on a small number of trips. The main demersal target species are hake, monkfishes, sea bass, common sole, turbot and Sparidae. About $70 \%$ of all boats operating in this area are smaller than $12 \mathrm{~m}$ length and perform a large number of short fishing trips (Leblond et al., 2010). The Northern site, where trawling is allowed, is characterized by pelagic and demersal fisheries targeting the same species along with cephalopods (Loligo spp, Sepia officinalis), which deploy mostly active gears. Pelagic species are mainly exploited by pelagic trawlers. Demersal species are exploited by bottom trawlers and gillnetters, the latter are the most important metiers in this area (92\% of the activity in number of months ; Leblond et al., 2010). Eighty percent of the boats that fished at least once in this area in 2008 were longer than $12 \mathrm{~m}$.

\subsection{Onboard observer programme}

Data from the French onboard observer programme contribute to the characterization of fishing pressure at the community level by providing information about the catch composition, as well as the characteristics and conditions of the fishing operation.

According to the sampling plan of the national programme, observers randomly select professional fishing boats to embark on, and once aboard randomly sample fishing operations (FOs). A FO includes all actions from the shooting to the hauling of the gear. The geographical positions, target species, gear and mesh size used, fishing time, and other information on the fisher's strategy and conditions of the FOs are recorded.

On sampled FOs, the whole catch is also recorded for both the landed and the discarded parts. All species of fish and commercial invertebrates are identified to the most precise level possible, ideally to the species level, counted, weighed (weight is sometimes calculated using the length/weight relationship) and measured.

The level of species identification can vary according to the observer's experience and/or the species. To circumvent this issue, 32 taxa which are difficult 
to identify were grouped here at the family or genus level (Allotheutis, Alosa, Argentina, Arnoglossus, Callionymus, Hippocampus, Labrus, Loligo, Lophius, Microchirus, Mullus, Mustelus, Octopus, Pagellus, Scomberomorus, Scorpaena, Scyliorhinus, Sepia, Seriola, Serranus, Solea except S. solea, Sparus, Syngnathus, Torpedo, Trachurus, Trisopterus, and families Carangidae, Gobiidae, Mugilidae, Palinuridae, Rajidae except Raja clavata and Leucoraja naevus, and Triglidae).

All observations from 2003 to 2012 were analysed together because of the limited quantity of data available on study sites. Additional observations carried out between July 2011 and December 2012 on coastal netters and longliners deployed around the Capbreton canyon in the context of the regional programme LOUPE (Observation of the habitat and associated communities in the context of the fisheries of the Capbreton Canyon) were also used in this study. They

\subsection{Catch metrics}

Since marine communities have different dimensions, three kinds of catch metrics were calculated (table 1): (i) species-based metrics to provide information on the number of species under fishing pressure and their relative abuncatch and its range, and (iii) functional metrics to provide information on the 
trophic composition of the catch. Mean length and median length provided similar results, so just mean length is reported below. For the functional metrics, each species was classified as piscivore or non-piscivore, based on the main diet of adult individuals (see Appendix).

Table 1: List of catch metrics $\left(n_{i}=\right.$ number of individuals for $i$ th species $; \mathrm{N}=$ total number of individuals $; L_{j}=j$ th length class in $\mathrm{cm} ; N_{j}=$ number at $j$ th length class $; L^{0.95}=$ quantile $95 \%$ of length distribution ; $L^{0.05}=$ quantile $5 \%$ of length distribution $; \mathrm{W}=$ weight ; pisc $=$ piscivores $; C=$ whole catch across all species $=$ landings + discards $)$ and method used for their estimation $(\mathrm{RC}=$ asymptote of rarefaction curve $; \tilde{x}=$ median of all resamples from sample sizes larger than $60 \%$ of the maximum sample size - see Section 2.3 and figure 2 ; $\bar{x}_{\text {logit }}=$ mean on all logit-transformed replicates from sample sizes larger than $60 \%$ of the maximum sample size - see Section 2.3 and figure 2).

\begin{tabular}{|c|c|c|c|c|c|}
\hline Type & Name & Code & Calculation & Description & Method \\
\hline \multirow[t]{2}{*}{ Species } & Richness & $S$ & & Number of species & $\mathrm{RC}$ \\
\hline & Evenness & $E_{1 / D}$ & $\begin{array}{l}\frac{1 / D}{S} \text { with } D= \\
\sum_{i}\left(\frac{n_{i}}{N}\right)^{2}\end{array}$ & $\begin{array}{l}\text { Variability in species abun- } \\
\text { dance (Simpson) }\end{array}$ & $\mathrm{RC}$ \\
\hline \multirow[t]{2}{*}{ Length } & Mean length & $\bar{L}$ & $\frac{\sum L_{j} \times N_{j}}{\sum N_{j}}$ & $\begin{array}{l}\text { Length of individuals in the } \\
\text { catch in } \mathrm{cm}\end{array}$ & $\tilde{x}$ \\
\hline & Length range & $\triangle L$ & $L^{0.95}-L^{0.05}$ & $\begin{array}{l}\text { Interpercentile range } 5-95 \% \\
\text { of length distribution in } \mathrm{cm}\end{array}$ & $\tilde{x}$ \\
\hline \multirow[t]{2}{*}{ Functional } & $\begin{array}{l}\text { Piscivore } \\
\text { weight pro- } \\
\text { portion }\end{array}$ & PWR & $\frac{\sum W_{p i s c}}{\sum W_{C}}$ & $\begin{array}{l}\text { Proportion of piscivores in } \\
\text { catch }\end{array}$ & $\bar{x}_{\text {logit }}$ \\
\hline & $\begin{array}{l}\text { Piscivore } \\
\text { number } \\
\text { proportion }\end{array}$ & PNR & $\frac{\sum N_{p i s c}}{\sum N_{C}}$ & $\begin{array}{l}\text { In comparison with PWR, } \\
\text { says if piscivores are larger } \\
\text { than other functional groups }\end{array}$ & $\bar{x}_{\text {logit }}$ \\
\hline
\end{tabular}

The FOs of passive and active gears cannot be directly compared because they use different capture processes based on different fish behaviours (Huse et al., 1999). Also for a given gear, the number of observed FOs per site differed (ta- 
ble 2). Sample size is known to affect the estimates of most selected metrics, they started to level off. They were estimated by determining the asymptote value and its associated standard deviation after fitting a Michaelis-Menten function: $S(n)=\frac{S \max \times n}{B+n}$, with $S$ the value of the metric, $S \max$ the asymp- 
(b)

Species

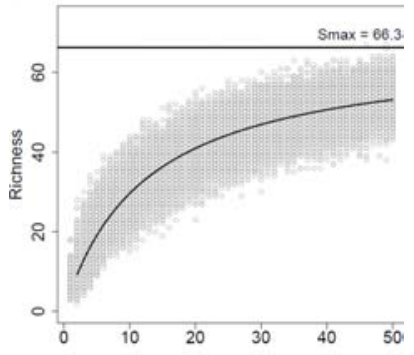

Length

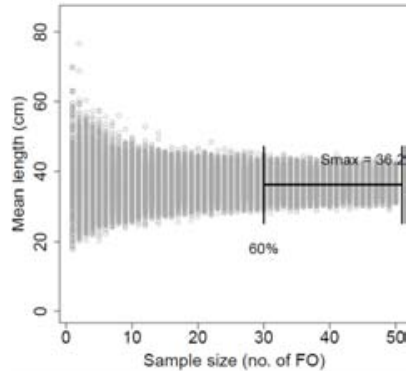

(c)

Functional composition

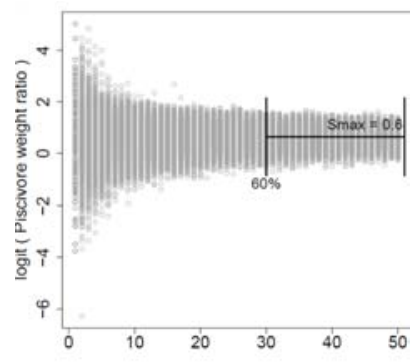

Figure 2: Methods for estimating metrics devoid of sample size effect and for standardizing catch characteristics between different passive and active gears, illustrated for gillnets in the Southern site : (a) rarefaction curve and asymptotic value of a fitted Michaelis-Menten model for species richness, (b) median of replicates resampled with sample size larger than $60 \%$ of the maximum sample size, for mean length, and (c) mean of logit-transformed replicates resampled with sample size larger than $60 \%$ of the maximum sample size, for piscivore weight proportion. 


\subsection{Metric comparison among gears and sites}

Rarefaction curves were used to estimate catch metrics standardized for sampling effort. One estimate was obtained for each gear-site combination. However, the estimates were associated with an uncertainty due to the variability between FOs. In order to account for this variability, a parametric resampling was carried out by randomly drawing 500 samples from a gaussian distribution $\mathcal{N}\left(\operatorname{Smax}, \sigma^{2}\right)$ with $\operatorname{Smax}$ the estimated value and $\sigma$ its associated standard deviation, for each gear-site combination. They are referred to as 'resamples'.

A two-way analysis of variance (ANOVA) was undertaken for all resamples separately for each metric to highlight significant effects of gear and site. For this ANOVA (A1) linear models with metric as response variable, and gear and site as factors, were fitted and the effects of the factors on each metric were tested by a Fisher's test. All gears were included. The percentage of variance explained by each factor was calculated as the sum of squares for each factor divided by the total sum of squares. Since the sample size was artificially increased by the parametric resampling, only the relative importance of factors, and not the full results, was displayed and discussed.

Multivariate analyses were also undertaken using the resamples from the different gears and sites as individuals and catch metrics as variables. A principal component analysis (PCA1) was carried out to examine the relationships between species, length and functional metrics. Groups of resampled replicates based on their center of gravity were visualised through starplots by site (North and South) and by gear.

For the comparison of gears deployed on both sites, a second ANOVA (A2) was performed including a gear-site interaction effect. The gear-site interaction informs on whether the differences between gears varied between sites. Such differences neither ascribable to the gear nor to the site (i.e. the environment of the FOs) would likely to be due to the way the gear was rigged and/or deployed in the site and thus resulting from different fishers' strategies. Bottom and pelagic trawls as well as longlines were removed from this analysis as they were only present on one of the sites. 
A second PCA (PCA2), similar to PCA1 but using only on resamples from the gears deployed in both sites was performed to highlight differences between sites by a given gear.

\section{Results}

\subsection{Description of observer data for study sites}

The number of observed fishing operations differed markedly between gears and sites ranging from 14 to 175 (table 2). All gears were mainly targeting bottom-dwelling species, the main target species were flatfish, gadoids and other demersal fish (table 2). The main mesh size used in both sites for all gears, except for bottom trawls, was $100 \mathrm{~mm}$. However, a wide range of mesh sizes were used by each gear, with a wider range in the South than in the North.

Table 2: Number of sampled fishing operations (FO) and characteristics from each site and gear in number of sampled vessels, main group of target species $(\mathrm{FLF}=$ flatfish, DEF $=$

demersal fish except gadoids, GAF = gadoid fish, MXF = diverse or unspecified fish) and mesh size mode with mesh size range in $\mathrm{mm}$.

\begin{tabular}{|c|c|c|c|c|c|c|}
\hline Site & $\begin{array}{l}\text { Gear } \\
\text { code }\end{array}$ & Gear name & $\begin{array}{l}\text { No of } \\
\text { FO }\end{array}$ & $\begin{array}{l}\text { No of } \\
\text { vessels }\end{array}$ & Targets & $\begin{array}{l}\text { Mesh size [min- } \\
\max ](\mathrm{mm})\end{array}$ \\
\hline \multirow[t]{3}{*}{ South } & $\mathrm{TN}$ & Trammel nets & 112 & 11 & FLF & $100[85-270]$ \\
\hline & GN & Gillnets & 175 & 14 & DEF, GAF, MXF & $100[50-190]$ \\
\hline & LL & Longlines & 12 & 5 & GAF, DEF & - \\
\hline \multirow[t]{4}{*}{ North } & $\mathrm{TN}$ & Trammel nets & 168 & 15 & FLF & $100[70-100]$ \\
\hline & GN & Gillnets & 36 & 5 & $\mathrm{DEF}$ & $100[84-110]$ \\
\hline & $\mathrm{PT}$ & Pelagic trawls & 14 & 7 & DEF, GAF, MXF & $100[16-100]$ \\
\hline & BT & Bottom trawls & 62 & 16 & FLF, MXF & $70[40-80]$ \\
\hline
\end{tabular}

The mean number of individuals per FO differed between fishing gears (figure 3 a). Bottom and pelagic trawls caught more individuals per FO than nets and 
longlines, with trammel nets catching an intermediate number of individuals.

In the South, the mean number of individuals caught was smaller than in the North, even for the same gear. The variability between FOs was large, especially for pelagic trawls.

Demersal fishes represented an important part of the catch for all gears (figure $3 \mathrm{~b}$ ). Benthic species also constituted an important part of the catch, especially benthic fish and crustaceans for bottom trawls, trammel nets and, to a lesser extent, gillnets in the Southern site. Pelagic species were caught in smaller proportions, even by pelagic trawls for which pelagic fishes represented less than $20 \%$ of the total catch weight.

Differences in catch lengths were observed, with bottom trawls catching the smallest individuals and longlines catching the largest ones (figure $3 \mathrm{c}$ ). All gears caught individuals of lengths comprised between 20 and $40 \mathrm{~cm}$.
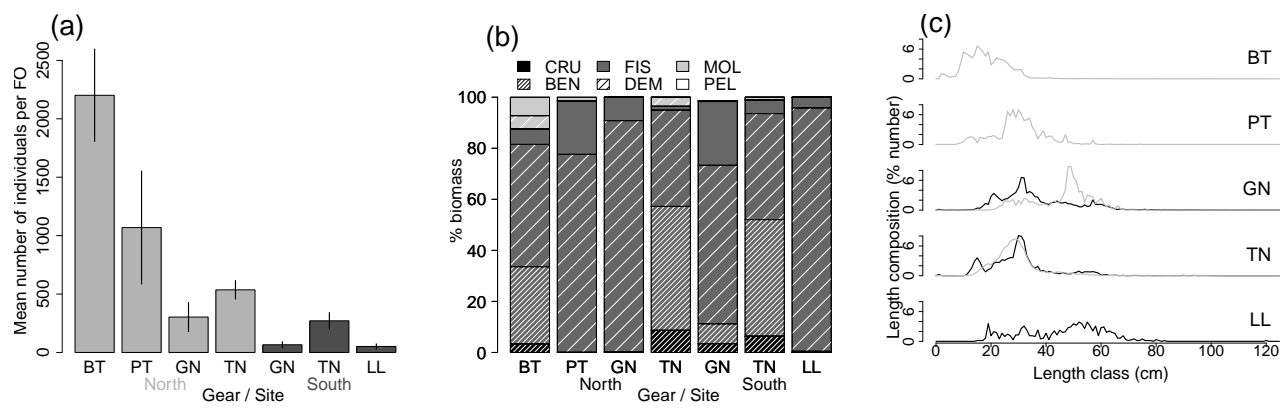

Figure 3: Characterization of catches in the Southern Bay of Biscay (2003-2012): (a) fishing intensity in mean number of individuals caught by each gear and site with vertical bars = 95\% confidence intervals, and (b-c) fishing distribution across community components : (b) composition of the catch in combined taxonomic group (CRU = crustacean; FIS $=$ fish; MOL $=$ mollusc) and main habitat $(\mathrm{BEN}=$ benthic; $\mathrm{DEF}=$ demersal; PEL = pelagic), and (c) length composition of the catch, for each gear $(\mathrm{BT}=$ bottom trawls $; \mathrm{GN}=$ gillnets $; \mathrm{LL}=$ longlines ; $\mathrm{PT}=$ pelagic trawls $; \mathrm{TN}=$ trammel nets) in the Southern site (black) and the Northern site (grey). 


\subsection{Catch metrics}

Species richness varied widely between gears (figure 4 a). Gillnets, trammel nets and bottom trawls caught a high number of species, while pelagic trawls caught a lower number of species and longlines caught less than 20 species. For gears being used in both sites (trammel nets and gillnets), richness was generally higher in the South than in the North, but this difference was not significant due to a high inter-FO variability.

There was no significant difference in evenness among gears (figure $4 \mathrm{~b}$ ). For the nets, the catch was generally more even in the South than in the North, though this difference was not significant.

Mean length varied between gears with longlines and gillnets catching the largest individuals, while bottom trawls caught smaller ones (figure $4 \mathrm{c}$ ). Both pelagic trawls and trammel nets caught intermediate lengths, with mean length around $30 \mathrm{~cm}$. Differences between the North and South differed among gears, mean length was similar for trammel nets, but smaller in the South for gillnets.

The length range was similar between gillnets, trammel nets and pelagic trawls, while it was larger for longlines and smaller for bottom trawls (figure 4 d). This means bottom trawls caught a narrower length range than other gears. The range of lengths caught was wider in the South than in the North for both gillnets and trammel nets.

The proportion of piscivores greatly differed between gears, with the proportion in weight being consistently larger than the proportion in numbers (figure 4 e, f). Longlines, gillnets and pelagic trawls had a catch dominated by piscivores, while piscivores were inferior to $40 \%$ in the catch of trammel nets and bottom trawls (figure $4 \mathrm{e}, \mathrm{f}$ ). The proportion of piscivores was similar between both sites for trammel nets but it was significantly lower for gillnets in the South than in the North. 


\section{Species}

(a)

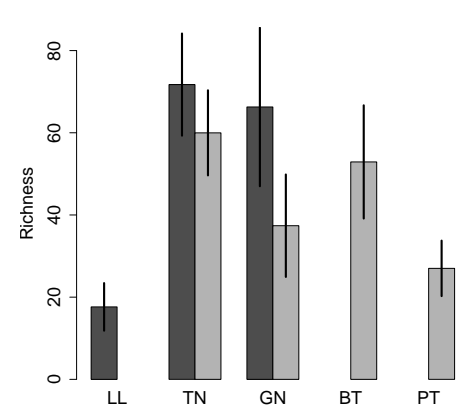

Length

(c)

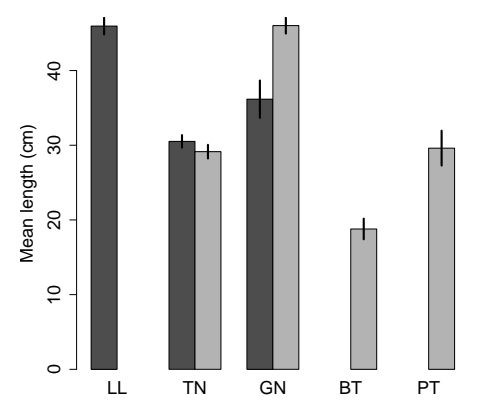

(b)

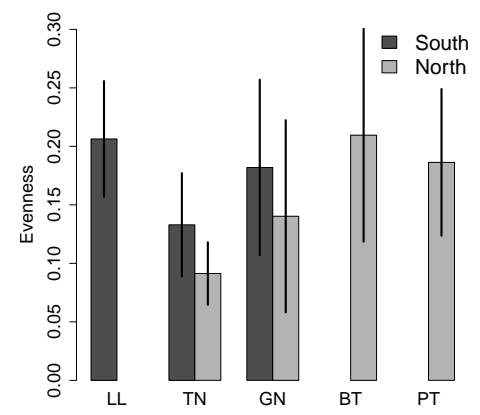

(d)

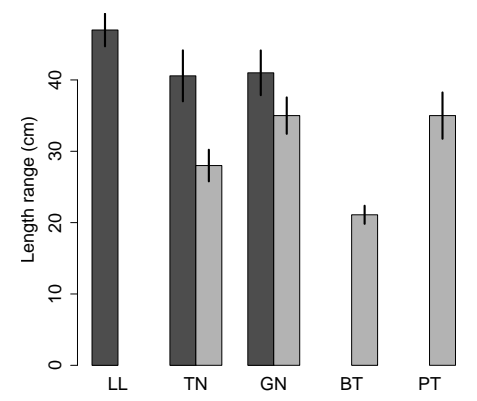

Functional composition

(e)

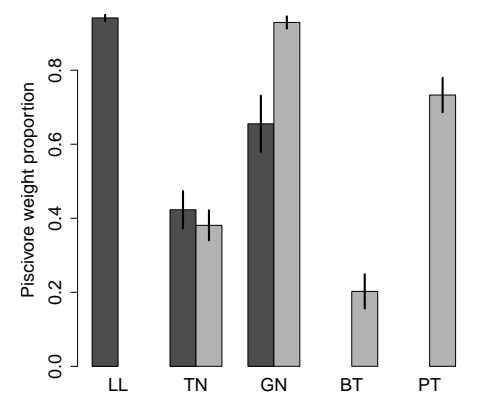

(f)

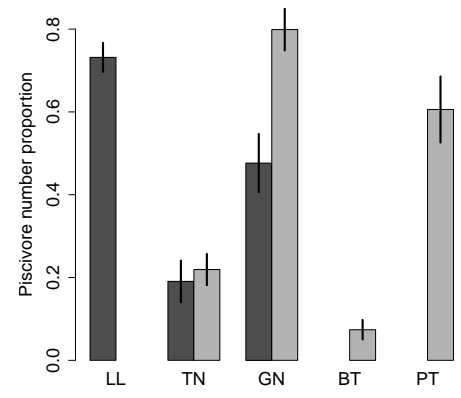

Gears

Figure 4: Estimated catch metrics in the Southern (black) and Northern (grey) sites : (a) richness, (b) Simpson's evenness, (c) mean length in $\mathrm{cm}$, (d) length range in $\mathrm{cm}$, (e) piscivore weight proportion, and (f) piscivore number proportion, by gear $(\mathrm{BT}=$ bottom trawls ; GN $=$ gillnets $; \mathrm{LL}=$ longlines $; \mathrm{PT}=$ pelagic trawls $; \mathrm{TN}=$ trammel nets). Vertical bars represent two standard deviations. 


\subsection{Comparison of catch between study sites harvested by different combinations}

among gears.

Table 3: Percentage of variance explained by gear and site for each catch metric from the analysis of variance undertaken on all gears deployed in each site (A1).

\begin{tabular}{lrrr}
\hline Metric & Gear & Site & \% residuals \\
\hline Richness & 56.6 & 12.3 & 31.1 \\
Evenness & 26.0 & 3.8 & 70.1 \\
Mean length & 89.0 & 2.9 & 8.1 \\
Length range & 69.7 & 18.0 & 12.3 \\
Piscivore weight proportion & 85.3 & 4.9 & 9.8 \\
Piscivore number proportion & 86.8 & 5.3 & 7.9 \\
\hline
\end{tabular}

The first two axes of the principal component analysis on all gears (PCA1) explained $79 \%$ of the total variance, with the first axis explaining $61 \%$. Along this axis, a strong positive correlation was found between both piscivore proportions, mean length and length range (figure 5 a). The higher the proportion of piscivores, the larger the individuals in the catch and the wider the length range. Richness was negatively correlated with length and functional metrics. The richer the catch, the smaller the proportion of piscivores, the smaller the 320 individuals, but also the narrower the length range. Evenness was nearly independent from length and functional metrics but was negatively correlated with richness. This means that catches made of a small number of species were more 
even.

(a)

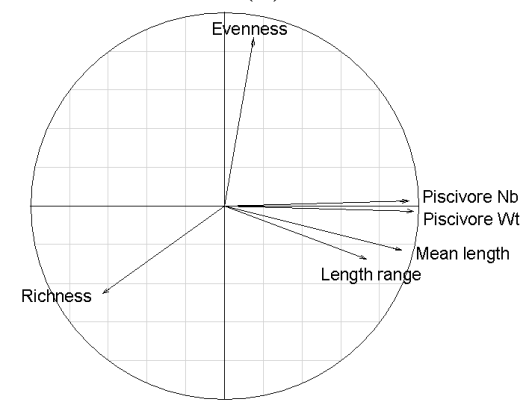

(b)

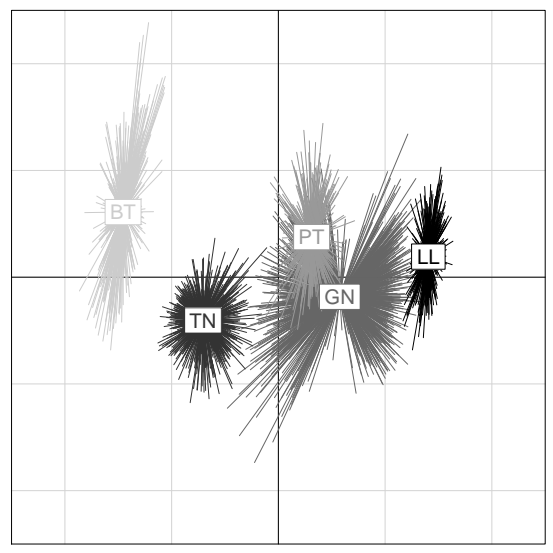

(c)

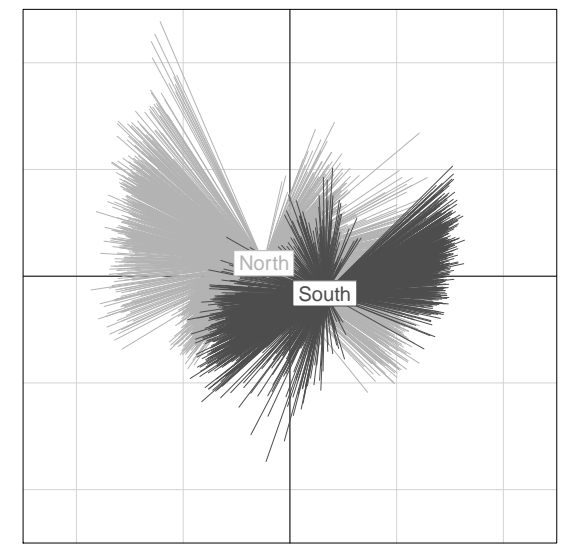

Figure 5: Principal component analysis of catch metrics for all gears deployed in each site (PCA1) with $61 \%$ of the variance explained by the 1 st axis, $18 \%$ explained by the 2 nd axis. (a) Catch metrics loadings ( $\mathrm{Nb}=$ number $; \mathrm{Wt}=$ weight $)$. Groups of resamples (b) by gear $(\mathrm{BT}=$ bottom trawls $; \mathrm{GN}=$ gillnets $; \mathrm{LL}=$ longlines $; \mathrm{PT}=$ pelagic trawls $; \mathrm{TN}=$ trammel nets) and (c) by site.

The grouping of resamples by gear clearly differentiated the gears, mainly along the length and functional metrics (figure $5 \mathrm{~b}$ ). Bottom trawls and trammel nets caught smaller individuals, a narrower length range and a smaller proportion of piscivore while longlines caught the largest individuals with a wide length range and a large proportion of piscivores (figure $5 \mathrm{~b}$ ). Pelagic trawls and gillnets were mainly differentiated by species metrics with gillnets having a richer catch (figure $5 \mathrm{~b}$ ). 
Small differences between the Southern and the Northern sites were observed, the length of the individuals caught in the Southern site were slightly larger and more dominated by piscivores than the catch in the Northern site (figure $5 \mathrm{c}$ ).

\subsection{Comparison of catch by similar gears between study sites}

Results from the ANOVA undertaken only on gears deployed in both sites, trammel nets and gillnets (A2) showed a significant effect of both gear and site on all metrics, as well as an effect of the gear-site interaction on all metrics except evenness (table 4 ).

While gear explained most of the variance for mean length and piscivore proportions $(>66 \%)$, site explained a greater variance part for length range and richness (table 4). The gear-site interaction explained a small percentage of the variance for all metrics, except for mean length and piscivore weight proportion $(>16 \%)$. The unexplained part remained high $(>50 \%)$ for evenness and richness.

Table 4: Percentage of variance explained by gear, site and gear-site interaction for each catch metric from the analysis of variance undertaken only on common gears deployed in both sites, trammel nets and gillnets (A2).

\begin{tabular}{lrrrr}
\hline Metric & Gear & Site & Gear-site interaction & \% residuals \\
\hline Richness & 11.7 & 30.6 & 5.9 & 51.9 \\
Evenness & 16.1 & 8.7 & 0.0 & 75.1 \\
Mean length & 69.2 & 9.4 & 16.6 & 4.8 \\
Length range & 9.6 & 60.5 & 7.4 & 22.5 \\
Piscivore weight proportion & 66.9 & 11.9 & 17.2 & 4.1 \\
Piscivore number proportion & 73.9 & 12.5 & 7.8 & 5.9 \\
\hline
\end{tabular}
separates gear from site effects, which were mixed in PCA1 due to differences in gear deployment between the two sites. Grouping resamples by gear clearly 
differentiated gillnets and trammel nets, mainly along the first PCA axis, with gillnets catching larger individuals and larger proportions of piscivores than trammel nets (figure $6 \mathrm{~b}$ ). Differences between the Southern and the Northern sites were observed mainly along the second PCA axis (figure $6 \mathrm{c}$ ). The catch was of wider length range, richer and more even in the Southern site than in the Northern site.

With PCA2, we can distinguish the metrics that discriminate gears from

\section{Discussion}

The first objective of this study was to propose a method to standardize and compare the distribution of catches across community components between

365 rarefaction curves were used to address this objective. This method, even if limited by the small number of observations for some gear-site combination, was found appropriate for this purpose because metrics converged for all combinations of gear-site.

370 The second objective of this study was to propose suitable metrics to characterize the distribution of catches across community components in species, length and function, that can highlight differences between gears. Length and functional metrics were found to be the most relevant metrics, in contrast to species metrics, for which a large part of the variance remained unexplained between gears, mainly in mean length and piscivore proportions. Smaller differ- 
(a)

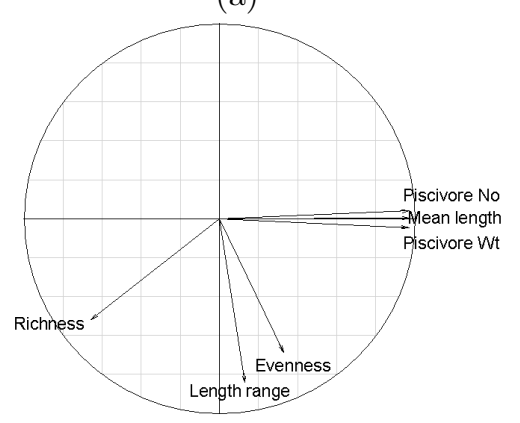

(b)

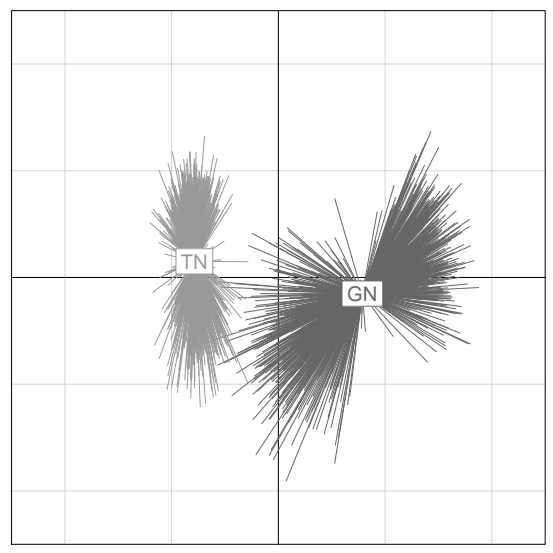

(c)

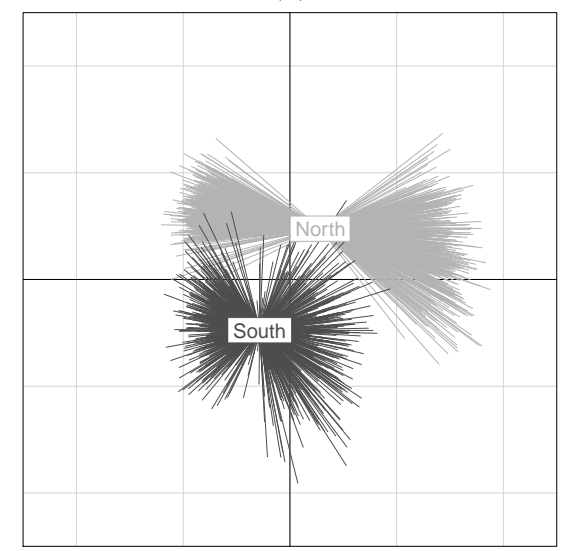

Figure 6: Principal component analysis of catch metrics for the gears deployed in both sites (PCA2) with $56 \%$ of the variance explained by the 1st axis, $24 \%$ explained by the 2 nd axis. (a) Catch metrics loadings $(\mathrm{Nb}=$ number ; $\mathrm{Wt}=$ weight $)$. Groups of resamples (b) by gear $(\mathrm{GN}=$ gillnets $; \mathrm{TN}=$ trammel nets $)$ and $(\mathrm{c})$ by site. 
ences were found between sites, mainly in length range and species richness. The effect of the gear-site interaction was also significant when comparing catches from the gears deployed on both sites only. This means that taking account of ing of the catch composition.

\subsection{Estimation method}

To characterize total fishing pressure at the community level, we need to take account of the pressures exerted by all gears deployed in a given area as well as the state of the community. None of the gears is likely to sample the whole community (Fraser et al., 2007; Huse et al., 2000). Instead, each gear will provide a restricted view of the marine community. Therefore, the state of the community remains unknown and pressure can only be characterized indirectly through catch. Characterizing the catch taken from the community implies to simulteanously take account of both active and passive gears. For passive gears standardization of sampling effort is difficult. In this study, the number of sampled fishing operations differed between gears and sites. This is known to affect diversity, especially species richness (Magurran \& McGill, 2011). Besides, fishing operations from different gears are not directly comparable, since gears have different capture processes which are based on different species behaviours. To overcome these problems, rarefaction curves were used to characterize the part of the community available to each gear. Since convergence with increasing sample size was observed on all gears and sites, we assume that rarefaction curves accordingly reached this objective and are appropriate to compare different passive and active gears.

The potential bias introduced by sample size when estimating biodiversity is widely recognized. However, it has not been as much examined for other metrics, such as individual length or functional composition of the catch. To avoid bias, we widened the use of sample-based rarefaction curves to length and functional metrics. Interestingly, convergence differed greatly between metrics. In contrast to species metrics which kept varying with increasing sample size, the length 
and functional metrics had a fast convergence with increasing sample size. It means that, despite a wide range of mesh sizes used for each gear, selection in length and functional composition from the community by the different gears was rather homogeneous. However, this fast convergence was favored because these metrics quantify an average property from a sample, while species metrics quantify unique observations, what partly explains why they converged more slowly.

However, a drawback of rarefaction curve is that it can be biased if sample size is too small (Gotelli \& Colwell, 2001). The limited number of observations for pelagic trawlers in the North and longliners in the South $(\mathrm{n}<20)$ might therefore bias our results on the differences by gear and site, especially for species metrics. The small number of observations further limited this study, by compelling to analyze all years and quarters together, which might mask seasonnal or annual effects. This data limitation has three main reasons. First, the number of trips to sample, as calculated for the sampling plan, is limited by technical and financial constraints. Second, the sampling plan is not fully realized owing to weather conditions and low acceptance of the programme by some professional fishers. Third, we had to focus on a small spatial scale, constrained by the need to find two sites broadly ecologically similar, differing in the way they were harvested, but partly exploited by similar gears. The sampling plan was not established for the purpose of this study but for estimating discarded amounts per fishing métier on all the French maritime areas. This study suggests that the amount of data necessary to characterize fishing pressure on marine communities, especially on species, is larger than to estimate discards. If onboard observer programmes were redesigned so as to be used to characterize fishing pressure on marine communities, the sampling plan should include all gears deployed in all areas, with a minimum sample size for each.

\subsection{Catch metrics}

A wide variety of metrics could be used to characterize catches at the community level. The ones selected for this study were intended to be simple and easy 
to interpret while describing the distribution of catches across different dimensions of the marine community : species, length, and function. Those metrics have been widely calculated from survey data as 'state' indicators to characterize fishing impacts on communities, including for the whole Bay of Biscay (e.g. Rochet \& Trenkel, 2005; Rochet et al., 2010; Shin et al., 2010). But we know of few studies estimating these metrics from catch data to characterize fishing pressure except Stergiou et al. (2002); Viana et al. (2013). However, because gears apply pressure on different components of the community (Piet et al., 2006), the use of such metrics to characterize pressure per gear appears necessary.

Length metrics, particularly mean length, and functional diversity in both number and weight were the most relevant to detect differences between gears and sites. The gears catching the largest fish were also catching the most piscivores in both number and weight. These patterns tend to confirm that piscivores were larger than other parts of the catch. Therefore, the classification of species into functional groups based on their diet as adults did not bias our results. The mean lengths of the catch found in this study, between 19 and $46 \mathrm{~cm}$, were larger than estimates calculated with the EVHOE bottom trawl survey data from the same sites, between 11 and $17 \mathrm{~cm}$ (Fauconnet, unpublished data). The same was true for piscivore proportions. Our estimates varied from 20 to $94 \%$ in weight and from 7 to $80 \%$ in number, while estimates from survey were much smaller : $<4 \%$ in weight, and $<1 \%$ in number (Fauconnet, unpublished data). This provides empirical evidence that commercial gears in general, but some more than others, select towards larger individuals and more piscivores than survey gear.

Species metrics were the metrics for which the smallest part of the variance was explained by the gears and sites. Small differences in evenness across gears can be due to fisheries targeting and catching mainly bentho-demersal species, many of which are solitary species. A catch made of gregarious species would have resulted less even than this. The small difference in evenness between fishing gears and sites can also result from the patchy sampling due to fishers targeting places where the resource is highly concentrated. Payne et al. 
(2005) found that Simpson's measure of evenness gives precise and unbiased estimates regardless of the underlying patchiness of the distribution, but it does not perform as well if the sampling is biased towards sites with greater number of organisms, as it is the case here. Evenness turned out not to be appropriate to detect differences between commercial gears. The grouping of species at genus or family level undertaken to get a consistent level of species identification across the whole dataset might have masked differences in richness and evenness between gears or sites. This highlights the importance of the quality of species identification in observer programmes, and that particular care should be taken, especially if the data are to be used for studies at the community level.

\subsection{Comparison between gears and sites}

Our results suggest that catch composition in species, length and function differ among gears. However, none of the gears was found to have the most, or least, diverse catch across all metrics. Notably, our results are not consistent with the prejudice that trawls have a more diverse catch than passive gears. Indeed, we found that the gears catching the largest individuals were also catching the widest length range. Bottom trawls caught smaller individuals than nets and longlines as expected, but with a narrower length range. This restricted length range can be explained by large fish being more efficient at escaping the trawl than smaller individuals (Huse et al., 2000). With respect to species, pelagic trawls had a slightly more even catch than gillnets but caught fewer species. These findings highlight that the criteria passive - active gears is not relevant to compare fishing pressures on marine communities. It further suggests that the aspect of diversity to be considered needs to be clearly explicited for management purpose, if fishing pressures are to be managed.

By comparing catches between two sites that are broadly similar ecologically, and differ in the way they are harvested but are partly exploited by similar gears, we were able to distinguish the effect of the gear from the effect of the site on the catch composition. Considering all gears, small differences were found between sites, with the catch from the South slightly larger-sized and with more piscivore 
than the catch from the North. However, the wider length range, and greater richness when only comparing gears deployed in both sites, characterizing the Southern site also proved that the catch was more heterogeneous in length and richer in this site compared to the Northern site. Those differences can be due to a difference of harvesting between sites (i.e. pressure), in particular to the trawling ban in the Southern site, or to the sites themselves (i.e. state). Even if the sites were selected to be as similar as possible, some structural and biological differences may exist between the two sites. For instance, the presence of the Capbreton canyon in the Southern site is known to attract mature hake (Sanchez \& Gil, 2000), while the Adour river plume plays an important role as a nursery for many species. The importance of both biological functions on this site might explain the wider length range observed. Studies on the annual variations would help in determining whether catches differed between sites because the underlying communities were different to start with (i.e. differences in state), or because they were harvested by different gear combinations (i.e. differences in pressure). This would further complete the knowledge of fishing pressure by taking account, besides their absolute values, of metric trajectories (Jennings, 2005). The Southern Bay of Biscay has been harvested for over a century, mostly by trawlers but also netters and longliners (Quero \& Cendrero, 1996). The catch composition has considerably changed since the beginning of the harvest. Back then, some large demersal piscivores were highly frequent in the catch, while now they are no longer found (Quero \& Cendrero, 1996). This historical record is qualitative though, and quantitative data have not been available for long enough to study in details the effects of fishing history on marine communities.

The gear-site interaction was tested to determine whether differences between sites varied between gears, which would likely result from differences in ${ }_{525}$ the way the gears were rigged and/or deployed in each site, i.e. from different fishers' strategies. The gear-site interaction which could only be tested for trammel nets and gillnets was significant for all metrics, particularly mean length and piscivore weight ratio, but not for evenness. The diversity of targets and 
strategies for those gears implies that the gear level may be too general, conindependant of mesh size and season, was informative to characterize pressure on species composition and diversity. Taking account of more information, such as target species and/or mesh size, could enable to more accurately characterize fishing pressure (Cornou et al., 2013; Dubé et al., 2012). Based on the catch be distinguished. The gears targeting benthic species, bottom trawls and trammel nets, tended to catch more species with a smaller mean length, a narrower length range and a smaller proportion of piscivores than the gears used to target gadoids or other demersal fish, i.e. gillnets, longlines and pelagic trawls. The 540 diversity of target species can also play an important role. While longlines often target a small number of species, bottom trawls are usually less specialized (Sanchez et al., 2013). Better understanding how targeting affects the catch composition might help assessing fishing pressures on marine communities.

\subsection{Conclusions}

545

This study aimed at characterizing fishing pressure at the community level based on onboard observer data. Total pressure on marine communities was estimated here as total catch, i.e. including discards. The latter can be a significant part of the catch and has been shown by Viana et al. (2013) to be important to estimate fisheries' ecological footprint. This study highlights the importance in observer programmes to consistently and exhaustively sample the total catch, i.e. both landings and discards of all species. Hovewer, even total catch is likely to underestimate pressure exerted by fisheries on marine communities. Indeed, it does not account for the mortality on individuals that were not brought onboard, for example those that escaped the gear with potential severe 555 injuries (Ingólfsson \& Jørgensen, 2006). Pressure on habitats and on benthic organisms could not be examined with the available data either. Indeed, for practical reasons, the protocol cannot include data collection on more species, and 'community' had to be restricted in this study to fish and commercial in- 
vertebrates. Some community components are likely to undergo more pressure than others, since targets and many catch components are similar between the different gears deployed in both sites. How the different gears compete with each other remains to be studied to highlight community components that are under higher pressure. In this study, we focused on how catches were distributed across community components. However pressure exerted on highly abundant or productive species will likely have different impacts than pressure exerted on rare or vulnerable species. A complementary approach would be to quantify the intensity of pressure undergone by each component, and their ability to sustain it, for example with methods such as the Productivity Susceptibitity Analysis (Smith et al., 2007). This study suggests that fishing pressure indeed varies among gears and among sites exploited by different gear combinations. The impacts of this contrasted pressure on marine communities remain to be studied.

\section{Acknowledgements}

We thank two anonymous referees for their comments and suggestions. Laurence Fauconnet received a PhD fellowship from the Région Pays de la Loire. Support provided by the French Department for Ecology, Sustainable development and Energy (Direction des Pêches Maritime et de l'Aquaculture), and the Pew Charitable Trusts. The opinions expressed are those of the authors and do not necessarily reflect the views of the funding organizations. The authors would like to thank Olivier Gaudou and Joël Diméet for their valuable contribution to the French observer programme and for their help in preparing the data for the analyses. We thank Jocelyne Martin and Pascal Laffargue for help in grouping the species. We also thank all fishers and observers who participated in the French observer programme. 
Alfaro-Shigueto, J., Mangel, J. C., Pajuelo, M., Dutton, P. H., Seminoff, J. A., \& Godley, B. J. (2010). Where small can have a large impact: Structure and characterization of small-scale fisheries in Peru. Fish. Res., 106, 8-17. doi:10.1016/j.fishres.2010.06.004.

Attwood, C. G., Petersen, S. L., \& Kerwath, S. E. (2011). Bycatch in South Africa's inshore trawl fishery as determined from observer records. ICES J. Mar. Sci., 68, 2163-2174. doi:10.1093/icesjms/fsr162.

Borja, A., Uriarte, A., \& Egaña, J. (2002). Environmental factors and recruitment of mackerel, Scomber scombrus L. 1758 , along the north-east Atlantic coasts of Europe. Fish. Oceanogr., 11, 116-127.

Borja, A., Uriarte, A., Egaña, J., Motos, L., \& Valencia, V. (1998). Relationships between anchovy (Engraulis encrasicolus) recruitment and environment in the Bay of Biscay (1967-1996). Fish. Oceanogr., 7, 375-380.

Chao, A., Chazdon, R. L., Colwell, R. K., \& Shen, T.-J. (2005). A new statistical approach for assessing similarity of species composition with incidence and abundance data: A new statistical approach for assessing similarity. Ecol. Lett., 8, 148-159. doi:10.1111/j.1461-0248.2004.00707.x.

Cornou, A.-S., Diméet, J., Tétard, A., Gaudou, O., Dubé, B., Fauconnet, L., \& Rochet, M.-J. (2013). Observations à bord des navires de pêche professionnelle - Bilan de l'échantillonnage 2012. Technical Report Ifremer. URL: http://archimer.ifremer.fr/doc/00167/27787/25978.pdf.

Dubé, B., Diméet, J., Rochet, M.-J., Tétard, A., Gaudou, O., Messannot, C., Fauconnet, L., Morizur, Y., Biseau, A., \& Salaun, M. (2012). Observations à bord des navires de pêche professionnelle - Bilan de l'échantillonnage 2011. RBE/STH/LTBH 2012-008 Ifremer. URL: http://archimer.ifremer.fr/doc/00109/21976/19586.pdf. 
Efron, B., \& Tibshirani, R. (1994). An Introduction to the Bootstrap. Number 57 in Monographs on Statistics \& Applied Probability (Chapman and Hall/CRC ed.).

European Union (2008). Commission Decision of 6 November 2008 adopting a multiannual Community programme pursuant to Council Regulation (EC) No 199/2008 establishing a Community framework for the collection, management and use of data in the fisheries sector and support for scientific advice regarding the common fisheries policy.

${ }_{620}$ Fraser, H. M., Greenstreet, S. P., \& Piet, G. J. (2007). Taking account of catchability in groundfish survey trawls: implications for estimating demersal fish biomass. ICES J. Mar. Sci., 64, 1800-1819.

Garcia, S. M., Kolding, J., Rice, J., Rochet, M.-J., Zhou, S., Arimoto, T., Beyer, J. E., Borges, L., Bundy, A., Dunn, D., Fulton, E. A., Hall, M., Heino, ${ }_{625}$ M., Law, R., Makino, M., Rijnsdorp, A. D., Simard, F., \& Smith, A. D. M. (2012). Reconsidering the consequences of selective fisheries. Science, 335, 1045-1047. doi:10.1126/science.1214594.

Garcia, S. M., Zerbi, A., Aliaume, C., Do Chi, T., \& Lasserre, G. (2003). The ecosystem approach to fisheries: issues, terminology, principles, institutional foundations, implementation and outlook. Number 443 in FAO Fisheries Technical Paper. Rome: Food \& Agriculture Organisation.

Gotelli, N. J., \& Colwell, R. K. (2001). Quantifying biodiversity: procedures and pitfalls in the measurement and comparison of species richness. Ecol. Lett., 4, 379-391.

Hall, M. A., Alverson, D. L., \& Metuzals, K. I. (2000). By-catch: Problems and solutions. Mar. Pollut. Bull., 41, 204-219.

Huse, I., C Gundersen, A., \& H Nedreaas, K. (1999). Relative selectivity of Greenland halibut (Reinhardtius hippoglossoides, Walbaum) by trawls, longlines and gillnets. Fish. Res., 44, 75-93. 
Huse, I., Løkkeborg, S., \& Soldal, A. V. (2000). Relative selectivity in trawl, longline and gillnet fisheries for cod and haddock. ICES J. Mar. Sci., 57, $1271-1282$.

Ingólfsson, O. A., \& Jørgensen, T. (2006). Escapement of gadoid fish beneath a commercial bottom trawl: relevance to the overall trawl selectivity. Fish. 645 Res., 79, 303-312.

Jennings, S. (2005). Indicators to support an ecosystem approach to fisheries. Fish Fish., 6, 212-232.

Jørgensen, E., \& Pedersen, A. R. (1998). How to obtain those nasty standard errors from transformed data - and why they should not be used: Internal report volume 7. Aarhus Universitet, Det Jordbrugsvidenskabelige Fakultet. URL: http://citeseerx.ist.psu. edu/viewdoc/download?doi=10.1.1.47.9023\&rep=rep1\&type=pdf.

Le Pape, O., Chauvet, F., Désaunay, Y., \& Guérault, D. (2003). Relationship between interannual variations of the river plume and the extent of nursery grounds for the common sole (Solea solea, L.) in Vilaine Bay. Effects on recruitment variability. J. Sea Res., 50, 177-185. doi:10.1016/S1385-1101(03)00061-3.

Le Suavé, R., Bourillet, J.-F., \& Coutelle, A. (2000). La marge nord du golfe de Gascogne: Connaissances générales et apport des nouvelles synthèses de données multifaisceaux. Technical Report Ifremer. URL: http://archimer.ifremer.fr/doc/00071/18199/.

Le Tixerant, M. (2006). Cartographie de la réglementation des pêches professionnelles-Régions Aquitaine et Poitou Charente. Technical Report Comités Régionaux des Pêches et des Élevages Marins de la région Aquitaine et de la région Poitou-Charentes, Association du Grand Littoral Atlantique (AGLIA). URL: http: //www . aglia. org/etudes . asp?Id=70\&Page=14\#Bottom. 
Leblond, E., Daures, F., Berthou, P., Merrien, C., Pitel-Roudaut, M., Brigaudeau, C., Demaneche, S., Jezequel, M., L'Equipe D'Exploitation Du Systeme Harmonie Du Sih, Bodere, E., \& Le Blond, S. (2010). Synthèse des flottilles de pêche 2008 Flotte Mer du Nord - Manche - Atlantique - Méditerranée. URL: http://archimer.ifremer.fr/doc/00003/11456/8013.pdf.

Magurran, A. E., \& McGill, B. J. (2011). Biological Diversity - Frontiers in Measurement and Assessment. New York: Oxford University Press.

Morandeau, G., Macher, C., Sanchez, F., Bru, N., Fauconnet, L., \& Caill-Milly, N. (2014). Why do fishermen discard? Distribution and quantification of the causes of discards in the Southern Bay of Biscay passive gear fisheries. Mar. Policy, 48, 30-38. doi:10.1016/j .marpol.2014.02.022.

Payne, L. X., Schindler, D. E., Parrish, J. K., \& Temple, S. A. (2005). Quantifying spatial pattern with evenness indices. Ecol. Appl., 15, 507-520.

Piet, G., Quirijns, J., Robinson, L., \& Greenstreet, S. (2006). Potential pressure indicators for fishing, and their data requirements. ICES J. Mar. Sci., 64, $110-121$.

Quero, J.-C., \& Cendrero, O. (1996). Incidence de la pêche sur la biodiversité ichtyologique marine: le bassin d'Arcachon et le plateau continental sud Gascogne. Cybium, 20, 323-356.

Quéro, J.-C., \& Vayne, J.-J. (2005). Les Poissons de mer des pêches françaises. Delachaux Et Niestlé.

Revill, A. (2012). Survival of discarded fish - A rapid review of studies on discard survival rates. Request for services commitment no. S12.615631. European Commission, Directorate - General for maritime affairs and fisheries, Policy development and coordination, Brussels, MAREA2. URL: http://nsrac.org/wp-content/uploads/2012/08/EU-discard-survival-short-study-version-001.p 
Rochet, M.-J., \& Trenkel, V. M. (2005). Factors for the variability of discards: assumptions and field evidence. Can. J. Fish. Aquat. Sci., 62, 224-235. doi:10.1139/f04-185.

Rochet, M.-J., Trenkel, V. M., Carpentier, A., Coppin, F., De Sola, L. G., Léauté, J.-P., Mahé, J.-C., Maiorano, P., Mannini, A., Murenu, M., Piet, G., Politou, C.-Y., Reale, B., Spedicato, M.-T., Tserpes, G., \& Bertrand, J. A. (2010). Do changes in environmental and fishing pressures impact marine communities? An empirical assessment. J. Appl. Ecol., 47, 741-750. doi:10.1111/j.1365-2664.2010.01841.x.

Sanchez, F., \& Gil, G. (2000). Hydrographic mesoscale structures and Poleward Current as a determinant of hake (Merluccius merluccius) recruitment in southern Bay of Biscay. ICES J. Mar. Sci., 57, 152-170.

Sanchez, F., Morandeau, G., Bru, N., \& Lissardy, M. (2013). A restricted fishing area as a tool for fisheries management: Example of the Capbreton canyon, southern Bay of Biscay. Mar. Policy, 42, 180-189. doi:10.1016/j.marpol.2013.02.009.

Shin, Y.-J., Bundy, A., Shannon, L. J., Simier, M., Coll, M., Fulton, E. A., Link, J. S., Jouffre, D., Ojaveer, H., \& Mackinson, S. (2010). Can simple be useful and reliable? Using ecological indicators to represent and compare the states of marine ecosystems. ICES J. Mar. Sci., 67, 717-731.

Smith, A. D. M., Fulton, E. J., Hobday, A. J., Smith, D. C., \& Shoulder, P. (2007). Scientific tools to support the practical implementation of ecosystembased fisheries management. ICES J. Mar. Sci., 64, 633-639.

Sourget, Q., \& Biais, G. (2009). Ecologie, biologie et exploitation $d u$ maigre $d u$ golfe de Gascogne. Rapport final convention SMIDDEST - IFREMER - CNRS. URL: 
Stergiou, K. I., Moutopoulos, D. K., \& Erzini, K. (2002). Gill net and longlines fisheries in Cyclades waters (Aegean Sea): species composition and gear competition. Fish. Res., 57, 25-37.

Viana, M., McNally, L., Graham, N., Reid, D. G., \& Jackson, A. L. (2013). Ignoring discards biases the assessment of fisheries' ecological fingerprint. Biol. Lett., 9, 20130812-20130812. doi:10.1098/rsbl.2013.0812. 
APPENDIX 
Table 1: Classification of species, genus or family by main habitat, taxonomic and functional groups (nei $=$ not elsewhere identified).

\begin{tabular}{|c|c|c|c|}
\hline Taxon & Main habitat & Taxonomic group & Functional group \\
\hline Alloteuthis & demersal & mollusc & non-piscivore \\
\hline Alopias vulpinus & pelagic & fish & piscivore \\
\hline Alosa & pelagic & fish & non-piscivore \\
\hline Argentina & pelagic & fish & non-piscivore \\
\hline Argyrosomus regius & demersal & fish & piscivore \\
\hline Arnoglossus & benthic & fish & non-piscivore \\
\hline Auxis rochei rochei & pelagic & fish & piscivore \\
\hline Balistes capriscus & demersal & fish & non-piscivore \\
\hline Belone belone & pelagic & fish & non-piscivore \\
\hline Beryx decadactylus & demersal & fish & piscivore \\
\hline Boops boops & pelagic & fish & non-piscivore \\
\hline Brama brama & demersal & fish & piscivore \\
\hline Buccinum undatum & benthic & mollusc & non-piscivore \\
\hline Buglossidium luteum & benthic & fish & non-piscivore \\
\hline Callionymus & benthic & fish & non-piscivore \\
\hline Cancer pagurus & benthic & crustacean & non-piscivore \\
\hline Carangidae & pelagic & fish & piscivore \\
\hline Cepola macrophthalma & demersal & fish & non-piscivore \\
\hline Ciliata mustela & demersal & fish & non-piscivore \\
\hline Citharus linguatula & benthic & fish & non-piscivore \\
\hline Clupea harengus & pelagic & fish & non-piscivore \\
\hline Conger conger & benthic & fish & piscivore \\
\hline Crangon crangon & demersal & crustacean & non-piscivore \\
\hline Dalatias licha & demersal & fish & piscivore \\
\hline Dasyatis pastinaca & benthic & fish & piscivore \\
\hline Delphinus delphis & pelagic & mammal & piscivore \\
\hline Dicentrarchus labrax & demersal & fish & piscivore \\
\hline Dicentrarchus punctatus & demersal & fish & piscivore \\
\hline Dicologlossa cuneata & benthic & fish & non-piscivore \\
\hline Diplodus cervinus & demersal & fish & non-piscivore \\
\hline Diplodus puntazzo & demersal & fish & non-piscivore \\
\hline
\end{tabular}




\begin{tabular}{|c|c|c|c|}
\hline Taxon & Main habitat & Taxonomic group & Functional group \\
\hline Diplodus sargus & demersal & fish & non-piscivore \\
\hline Diplodus vulgaris & demersal & fish & non-piscivore \\
\hline Echiichthys vipera & benthic & fish & non-piscivore \\
\hline Engraulis encrasicolus & pelagic & fish & non-piscivore \\
\hline Euthynnus alletteratus & pelagic & fish & piscivore \\
\hline Gadus morhua & demersal & fish & piscivore \\
\hline Galeorhinus galeus & demersal & fish & piscivore \\
\hline Galeus melastomus & demersal & fish & piscivore \\
\hline Gobiidae & benthic & fish & non-piscivore \\
\hline Helicolenus dactylopterus & demersal & fish & non-piscivore \\
\hline Heptranchias perlo & demersal & fish & piscivore \\
\hline Hexanchus griseus & demersal & fish & piscivore \\
\hline Hippocampus & benthic & fish & non-piscivore \\
\hline Homarus gammarus & benthic & crustacean & non-piscivore \\
\hline Illex coindetii & pelagic & mollusc & non-piscivore \\
\hline Labrus & demersal & fish & non-piscivore \\
\hline Lepidorhombus whiffiagonis & benthic & fish & piscivore \\
\hline Leucoraja naevus & benthic & fish & piscivore \\
\hline Limanda limanda & benthic & fish & non-piscivore \\
\hline Lithognathus mormyrus & demersal & fish & non-piscivore \\
\hline Loligo & pelagic & mollusc & non-piscivore \\
\hline Lophius & benthic & fish & piscivore \\
\hline Maja brachydactyla & benthic & crustacean & non-piscivore \\
\hline Melanogrammus aeglefinus & demersal & fish & non-piscivore \\
\hline Merlangius merlangus & demersal & fish & piscivore \\
\hline Merluccius merluccius & demersal & fish & piscivore \\
\hline Microchirus & benthic & fish & non-piscivore \\
\hline Micromesistius poutassou & pelagic & fish & non-piscivore \\
\hline Mola mola & pelagic & fish & piscivore \\
\hline Molva molva & demersal & fish & piscivore \\
\hline Mugilidae & demersal & fish & non-piscivore \\
\hline Mullus & benthic & fish & non-piscivore \\
\hline Mustelus & demersal & fish & piscivore \\
\hline
\end{tabular}




\begin{tabular}{|c|c|c|c|}
\hline Taxon & Main habitat & Taxonomic group & Functional group \\
\hline Myliobatis aquila & benthic & fish & piscivore \\
\hline Necora puber & benthic & crustacean & non-piscivore \\
\hline Nephrops norvegicus & benthic & crustacean & non-piscivore \\
\hline Octopus & benthic & mollusc & non-piscivore \\
\hline Pagellus & demersal & fish & piscivore \\
\hline Pagrus pagrus & demersal & fish & piscivore \\
\hline Palinuridae & benthic & crustacean & non-piscivore \\
\hline Pecten maximus & benthic & mollusc & non-piscivore \\
\hline Pegusa lascaris & benthic & fish & non-piscivore \\
\hline Petromyzon marinus & demersal & fish & non-piscivore \\
\hline Phocoena phocoena & pelagic & mammal & piscivore \\
\hline Phrynorhombus norvegicus & benthic & fish & non-piscivore \\
\hline Platichthys flesus & benthic & fish & piscivore \\
\hline Pleuronectes platessa & benthic & fish & piscivore \\
\hline Pollachius pollachius & demersal & fish & piscivore \\
\hline Pollachius virens & demersal & fish & piscivore \\
\hline Polyprion americanus & demersal & fish & piscivore \\
\hline Prionace glauca & pelagic & fish & piscivore \\
\hline Phycis blennoides & demersal & fish & non-piscivore \\
\hline Phycis phycis & demersal & fish & non-piscivore \\
\hline Raja clavata & benthic & fish & piscivore \\
\hline Rajidae nei & benthic & fish & piscivore \\
\hline Salmo salar & demersal & fish & piscivore \\
\hline Salmo trutta trutta & demersal & fish & piscivore \\
\hline Sarda sarda & pelagic & fish & piscivore \\
\hline Sardina pilchardus & pelagic & fish & non-piscivore \\
\hline Sarpa salpa & demersal & fish & non-piscivore \\
\hline Scomber colias & pelagic & fish & non-piscivore \\
\hline Scomber scombrus & pelagic & fish & non-piscivore \\
\hline Scomberomorus & pelagic & fish & piscivore \\
\hline Scophthalmus maximus & benthic & fish & piscivore \\
\hline Scophthalmus rhombus & benthic & fish & piscivore \\
\hline Scorpaena & benthic & fish & piscivore \\
\hline
\end{tabular}




\begin{tabular}{llll}
\hline Taxon & Main habitat & Taxonomic group & Functional group \\
\hline Scyliorhinus & demersal & fish & piscivore \\
Sepia & demersal & mollusc & non-piscivore \\
Seriola & pelagic & fish & piscivore \\
Serranus & demersal & fish & piscivore \\
Solea nei & benthic & fish & non-piscivore \\
Solea solea & benthic & fish & non-piscivore \\
Sparus & demersal & fish & piscivore \\
Spondyliosoma cantharus & demersal & fish & non-piscivore \\
Sprattus sprattus & pelagic & fish & non-piscivore \\
Squalus acanthias & demersal & fish & piscivore \\
Stenella coeruleoalba & pelagic & mammal & piscivore \\
Syngnathus & benthic & fish & non-piscivore \\
Torpedo & benthic & fish & piscivore \\
Trachinus draco & benthic & fish & non-piscivore \\
Trachurus & pelagic & fish & non-piscivore \\
Triglidae & benthic & fish & non-piscivore \\
Trisopterus & demersal & fish & non-piscivore \\
Umbrina canariensis & demersal & fish & non-piscivore \\
Umbrina cirrosa & demersal & fish & non-piscivore \\
Zeus faber & demersal & fish & piscivore \\
\hline & & & \\
\hline
\end{tabular}

